\title{
PERAN ORANG TUA DALAM PROSES AKSEPTABILITAS MASYARAKAT TERHADAP ANAK PENYANDANG TUNA GRAHITA DI KOTA YOGYAKARTA
}

\author{
Ratna Dewi \\ Fakultas Ekonomi dan Ilmu Sosial UIN Suska Riau \\ ratna.dewi@uin-suska.ac.id \\ Zarkasih \\ Fakultas Tarbiyah dan Keguruan UIN Suska Riau \\ zarkasih@uin-suska.ac.id
}

\begin{abstract}
Abstrak
Penyandang tuna grahita sering mendapat perlakuan marginal dari masyarakat luas. Penelitian ini bertujuan meninjau bagaimana peran orang tua dalam proses akseptabilitas masyarakat terhadap anak-anak penyandang tuna grabita di kota Yogyakarta. Penelitian ini menggunakan tinjauan rasionalitas Weber dalam melihat peran-peran yang dilakukan orang tua kepada anaknya yang menyandang tuna grabita. Dengan metode kualitatif melalui pendekatan fenomenologis peneliti melihat babwa setiap orang tua mempunyai rasionalitas sendiri mengenai tindakan atau peran yang dilakukannya yang mengarah pada penerimaan masyarakat terhadap anaknya yang menyandang tuna grabita. Peran yang dilakukan oleh para orang tua itu tergantung pada sikap atau reaksi mereka terhadap kehadiran anaknya yang menyandang tuna grabita. Orang tua yang dapat menerima keadaan anaknya akan berusaha semaksimal mungkin untuk mendidik dan membawa anaknya beradaptasi dan melakukan interaksi sosial dengan masyarakat, sehingga masyarakat pun menjadi lebih mudah untuk menerima keadaan anak penyandang tuna grahita tersebut. Sebaliknya, orang tua yang sulit menerima kondisi anaknya yang menyandang tuna grabita, akan berusaha membatasi ruang gerak dan ruang interaksi sosial anak, sehingga masyarakat pun cendrung sulit menerima keterbatasan dan kehadiran anak penyandang tuna grabita.
\end{abstract}

Kata Kunci: akseptabilitas, tuna grabita, peran orang tua

\begin{abstract}
People with visual impairment often receive marginal treatment from the wider community. This study aims to review how the role of parents in the process of acceptance of society against children with visual impairment in Yogyakarta. This study used a review of Weber's rationality in looking at the roles that parents do to their children who suffer from mental illiteracy. With qualitative method through phenomenological approach the researcher see that every parents have their own rationality about action or role that do that leads to the acceptance of society to its child who bears mentality. The roles performed by the parents are dependent on their attitude or reaction to the presence of their child who bears the mentality. Parents who can accept the circumstances of their children will try as much as possible to educate and bring their children to adapt and social interaction with the community, so that people become easier to accept the state of children with mental illiteracy. Otherwise, parents who are difficult to accept the condition of children who bear the mentality, will try to limit the space and space of sosial interaction of children, so that the community also tends hard to accept the limitations and the presence of children with visual impairment.
\end{abstract}

Keywords: acceptability, tuna grabita, role of parents.

\section{PENDAHULUAN}

Di Indonesia, pada umumnya masyarakat yang mengkalim diri mereka normal menganggap para penyandang tuna grahita atau yang lebih dikenal dengan sebutan idiot, tidak dapat ditingkatkan kemampuan berfikirnya, walaupun sudah menjalani pendidikan di sekolah luar biasa. Mereka cenderung menyepelekan kemampuan penyandang cacat tuna grahita. Image atau pemikiran negative tersebut sudah menjadi rahasia umum. Sehingga penyandang tuna grahita mempunyai hambatan untuk berkembang dalam berbagai aspek kehidupan seperti aspek sosial, politik, budaya dan ekonomi.

Dalam aspek sosial misalnya, penyandang tuna grahita memiliki pergaulan yang terlalu sempit karena mereka sering dikucilkan dari lingkungan bermain dengan teman-teman sebayanya atau bahkan menjadi bahan ejekan dan olokan dari teman-teman sebayanya tersebut. Sehingga banyak 
orang tua yang tidak tega melihat perlakukan marginal yang dialami anaknya dan mereka "mengurung" anaknya di rumah atau hanya memberikan ruang sosial yang terbatas pada lingkungan keluarga saja.

Dalam bidang politik, sering kali hak-hak politik para penyandang cacat terutama penyandang tuna grahita diabaikan oleh pemerintah. Salah satu buktinya adalah kurang diperhitungkannya partisipasi dan aspirasi para penyandang cacat dalam agenda-agenda politik di Negara ini.

Begitu juga dalam bidang budaya. Para penyandang tuna grahita sering dianggap tidak layak mengembangkan kebudayaan bangsa dan Negara. Karena penyandang tuna grahita merupakan orang yang idiot, yang tidak mampu berfikir waras atau normal. Mereka bahkan mempunyai kebiasaan yang aneh, yang tidak sama seperti orang lain pada umumnya, yang tidak sesuai dengan standar normal. Bahkan tidak jarang mereka tidak dapat menjaga kebersihan dirinya sendiri. Kondisi yang demikian, yang lagi-lagi membuat penyandang tuna grahita mendapat perlakuan marginal.

Hal-hal tersebut di atas menjadi tantangan bagi orang tua yang mempunyai anak-anak penyandang tuna grahita. Orang tua mempunyai peran yang sangat penting bagi pertumbuhan dan perkembangan anak dalam semua aspek, seperti perkembangan fisik, intelektual, emosi, moral, kepribadian, dan spiritual. Kebutuhan dasar yang harus dipenuhi bagi seorang anak agar dapat mencapai tumbuh kembang yang optimal adalah kebutuhan akan kedekatan psikologis, kebutuhan fisik dan mental serta kebutuhan rasa aman.

Sebelum seorang anak terjun ke dalam lingkungan sosial yang lebih luas yaitu masyarakat, ia terlebih dahulu memasuki lingkungan yang lebih kecil, yaitu keluarganya. Begitu pula halnya dengan anak-anak tuna grahita. Sebelum mereka diterima oleh masyarakatnya, mereka harus diterima terlebih dahulu oleh keluarganya, terutama oleh orang tua dan saudara-saudaranya. Sehingga apabila mereka menghadapi hambatan atau kesulitan dalam proses sosialisasinya dalam masyarakat, keluarga siap memberikan dukungan dan solusi untuk membantunya. Dalam hal ini orang tua mempunyai peran yang sangat besar untuk menentukan masa depan anak-anaknya, dan agar anak-anaknya dapat diterima di dalam masyarakat dengan baik.

\section{Kajian Rasionalitas Weber}

Untuk memahami tindakan orang tua, maka kita perlu mengkaji teori rasionalitas Weber terlebih dahulu. Weber mengatakan pandangannya dalam From Max Weber (1946: 55) sebagai berikut:

Sosiologi interpretative memandang individu dan tindakannya sebagai satuan dasar, sebagai "atom-nya. Dalam pendekatan ini individu juga yang paling penting dan satu-satunya yang melaksanakan tindakan yang berarti itu... Umumnya bagi sosiologi, konsep-konsep seperti "negara, "perserikatan, "feodalisme" dan sebagainya menunjukkan kategori-kategori tertentu dalam interaksi manusia. Karena itu adalah tugas sosiologi untuk mereduksi konsep ini ke tindakan "yang dapat dimengerti, artinya tanpa kecuali ke tindakan orang-orang yang berpartisipasi secara individual.

Pernyataan Weber tersebut mengandung makna akan pentingnya pemahaman subyektif (verstehen) sebagai metode untuk memperoleh pemahaman yang valid mengenai arti-arti subjektif tindakan sosial. Dalam hal ini Weber memandang bahwa untuk dapat memahami arti-arti subjektif dan tindakan-tindakan sosial seseorang atau orang lain diperlukan kemampuan untuk menempatkan diri dalam kerangka berfikir orang lain yang perilakunya ingin dijelaskan, dan situasi serta tujuan-tujuannya akan dilihat.

Dalam paradigma defenisi sosial melalui exemplar dari Weber menjelaskan analisanya tentang tindakan sosial individu. Ia tidak memisahkan secara tegas antara struktur sosial dan pranata sosial dan menganggap keduanya membantu membentuk tindakan manusia yang penuh arti atau penuh makna. Ia mengungkapkan bahwa tindakan sosial bersifat subjektif yang mungkin terjadi karena pengaruh situasi yang positif. Individu memiliki motivasi dan kebutuhan-kebutuhan internal alami yang melatarbelakangi tindakannya tersebut (Alimandan, 1985: 45).

Weber mengklasifikasikan tindakan sosial kedalam tindakan rasional dan tindakan non rasional. Tindakan rasional merupakan tindakan yang didasari atas pertimbangan-pertimbangan yang sadar dan pilihan bahwa tindakan itu dinyatakan (Robert, M.Z. Lawang, 1986: 117). Pembahasan dalam penelitian ini lebih ditekankan 
kepada tindakan rasional, yang mencakup rasionalitas instrumental dan rasionalitas nilai. Hal ini didasarkan atas pertimbangan keterkaitannya dengan tindakan orang tua menyekolahkan anaknya (penyandang tuna grahita) di SLB C Negeri Yogyakarta.

\section{METODE}

Penelitian ini menggunakan metode kualitatif dengan pendekatan fenomenologis. Penelitian fenomenologis lebih menekankan pada aspek subjektif dari perilaku orang. Peneliti berusaha untuk masuk ke dalam dunia konseptual para subjek yang ditelitinya sedemikian rupa sehingga peneliti mengerti apa dan bagaimana suatu pengertian akan dikembangkan (Moleong, 2001:9). Dengan kata lain peneliti berusaha mamahami perilaku manusia dari segi kerangka berfikir maupun bertindak orang-orang yang diteliti tersebut.

Subjek dalam penelitian ini adalah para orang tua anak-anak penyandang tuna grahita yang menyekolahkan anaknya di SLB C Negeri 1 Bintaran Yogyakarta dan masyarakat yang tinggal di sekitar tempat tinggal anak-anak penyandang tuna grahita tersebut. Penentuan subjek penelitian ini adalah berdasarkan teknik pusposive sampling, yaitu subjek yang dipilih berdasarkan tujuan dan pertimbangan informasi yang diperlukan. Di samping itu peneliti juga menggali informasi dari Kepala sekolah SLB C Negeri 1 Bintaran Yogyakata, para guru yang mengajar dan mendidik di sana, dan para pedagang yang menjual makanan di lingkungan SLB C tersebut. Dalam hal ini mereka berperan sebagai informan dalam rangka meng-kroscek atau memperdalam informasi yang didapatkan dari subjek penelitian.

Peneliti melakukan penelitian selama empat bulan di Kota Yogyakarta, dengan melakukan observasi non partisipan, wawancara mendalam terhadap subjek dan informan penelitian, pengumpulan dokumentasi yang terdiri dari tulisan atau artikel, surat-surat atau dokumentasi resmi, foto-foto, dan bahan-bahan pustaka yang membahas masalah yang sama dengan penelitian ini. Di samping itu, pada waktu pengumpulan data di lapangan, peneliti juga membuat catatan lapangan yang berupa coretan seperlunya yang sangat dipersingkat berisi kata-kata inti, frase, pokok-pokok isi pembicaraan atau pengamatan. Catatan itu baru diubah ke dalam catatan yang lengkap setelah peneliti tiba dirumah. Proses ini dilakukan setiap kali peneliti selesai mengadakan pengamatan dan wawancara. Hal ini penting dilakukan karena ingatan seseorang itu sifatnya terbatas (Moleong, 188: 152).

Dalam penelitian ini peneliti merupakan perencana, pelaksana pengumpulan data, analisis penafsir data, dan pada akhirnya peneliti menjadi pelapor hasil penelitian. Sehingga kedudukan peneliti sebagai instrument atau alat penelitian di sini sangat tepat karena peneliti menjadi segalanya dari keseluruhan proses penelitian (Moleong, 1988: 121).

Untuk memeriksa keabsahan data, peneliti melakukan beberapa cara yaitu melakukan ketekunan pengamatan agar menemukan ciri-ciri dan unsur-unsur dalam situasi yang sangat relevan dengan persoalan atau isu yang sedang dicari, dan kemudian memusatkan diri pada hal-hal tersebut secara rinci. Kemudian peneliti menguji keabsahan data dengan cara triangulasi, yaitu dengan memanfaatkan sesuatu yang lain di luar data itu sendiri. Denzim membedakan empat macam, triangulasi yaitu memanfaat penggunaan sumber, metode, penyidik dan teori. (Moleong, 1994: 178). Dalam penelitian ini, teknik triangulasi yang dipakai oleh peneliti lebih banyak bersandar pada pemanfaatan penggunaan sumber. Dengan memakai cara pemanfatan penggunaan sumber, peneliti membangun suatu pola tertentu untuk menguji kebenaran dan keabsahan data dengan memanfaatkan informasi dari informan.

Dan yang terakhir peneliti melakukan diskusi dengan rekan sejawat untuk mengekspos hasil sementara atau hasil akhir penelitian. Dengan melakukan diskusi analitik dapat menunjukkan kekurangan dan kelebihan dari hasil penelitian serta mendapatkan masukan-masukan yang sangat bermanfaat dalam penyempurnaan hasil penelitian.

\section{HASIL DAN PEMBAHASAN}

Jika seorang anak tuna grahita mengalami penyimpangan dalam proses tumbuh kembangnya, ia tidak dapat mengikuti beberapa tahap kehidupan sosial yang lazimnya dilalui oleh anak normal. Misalnya seorang anak tidak bisa menyebutkan bilangan 1-10 walaupun ia sudah berusia 6 tahun. Hal ini merupakan konsekwensi logis dari perbedaan atau kekurangan yang 
disandangnya. Akan tetapi banyak orang tua yang tidak menyadari kekurangan yang disandang anaknya tersebut. Sehingga mereka sering kali memaksakan anaknya untuk mampu mengikuti tahap-tahap kehidupan sosial yang lazimnya diikuti oleh anak-anak yang normal, dan mereka akan mulai merasa cemas atau khawatir manakala anaknya tersebut tidak mampu mengikutinya. Ketakutan atau kekhawatiran orang tua itu muncul karena merujuk pada kebiasaan-kebiasaan yang dianggapnya sebagai suatu keharusan.

Berkaitan dengan kekhawatiran orang tua tersebut, Atmodiwirjo (Tatiana, 1997) mengemukakan tiga tahap yang umumya dialami orang tua sebelum mereka benar-benar bisa menerima kehadiran anaknya yang cacat. Tahaptahap tersebut adalah:

1. Tahap pengingkaran (denial)

Merupakan saat pertama ketika orang tua mengetahui bahwa anaknya menyandang kecacatan. Biasanya mereka tidak mempercayai dan berusaha mencari ahli-ahli lain dengan harapan diagnosa kecacatan yang disandang anaknya itu keliru.

2. Tahap penerimaan secara intelektual, namun secara emosional terdapat rasa marah, rasa bersalah serta depresi.

Pada tahap ini, orang tua lebih menyibukkan diri dengan perasaannya daripada melakukan usaha-usaha yang dapat membantu anak. Umumnya perlakuan orang tua terhadap anak pada tahap ini adalah sangat membatasi aktivitas anak, sehingga anak menjadi tidak mandiri bahkan sangat tergantung.

3. Tahap penerimaan secara intelektual dan emosional.

Pada tahap ini orang tua lebih bersikap realistis, bahkan konstruktif dan memiliki keinginan untuk mengikuti aktivitas programprogram bagi anak-anak cacat. Baik itu berupa support, maupun peran serta secara langsung. Keterlibatan orang tua semacam ini sangat membantu atau berperan dalam proses akseptabilitas masyarakat terhadap anak penyandang cacat umumnya dan penyandang tuna grahita khususnya.

Tidak semua orang tua menjalani tahaptahap demikian. Hal ini tergantung pada kondisi anak, kepribadian orang tua serta kondisi lingkungan di sekitarnya. Adapun para orang tua yang menjadi subjek penelitian ini memiliki kepribadian yang sangat beragam, sesuai dengan latar belakang pendidikannya, pekerjaannya dan lingkungan masyarakatnya. Dan mereka juga memiliki anak penyandang tuna grahita yang berbeda pula kondisinya.

Pada umumnya ketika orang tua pertama kali mengetahui bahwa anak mereka menyandang cacat mental (tuna grahita), mereka mempunyai rasa malu dan rasa minder atau rendah diri. Dan karena perasaan mereka itu, mereka berusaha menutup diri dari pergaulan dengan masyarakat. Sekalipun ada kegiatan-kegiatan sosial di lingkungan masyarakatnya mereka keberatan membawa putra mereka yang cacat tersebut ikut hadir bersama mereka di tengah-tengah masyarakat. Tahap inilah yang disebut oleh Atmodowirdjo sebagai tahap pengingkaran.

Pada dasarnya perasaan malu yang dirasakan oleh orang tua anak-anak penyandang cacat mental tersebut merupakan hal yang wajar. Hal ini sesuai dengan yang dikatakan oleh Dr. Sarlito Wirawan (1994) bahwa salah satu perilaku yang ada pada setiap manusia adalah rasa malu. Menurutnya malu adalah suatu perasaan yang timbul pada diri seseorang bila ia tampil di depan umum atau di tengah-tengah masyarakat dalam keadaan yang tidak sesuai dengan harapan orang banyak terhadap dirinya.

Dari hasil observasi dan wawancara mendalam di lapangan peneliti menemukan beberapa fakta bahwa terdapat reaksi atau sikap yang berbedabeda yang dilakukan oleh para orang tua yang memiliki anak penyandang tuna grahita. Reaksi tersebut dapat berdampak positif dengan segala proses yang meyertainya seperti yang diungkapkan oleh Atmodowirdjo di atas, namun ada juga yang kemudian berdampak negative terhadap perkembangan anak penyandang tuna grahita, yang meliputi:

1. Sikap terlalu melindungi (over protective)

2. Sikap serba membolehkan (permissive)

3. Sikap menolak

4. Sikap mendominasi

5. Serta sikap mengalah.

Kemudian dari temuan tersebut, peneliti mengkalsifikan peran orang tua penyandang tuna grahita dalam proses akseptabilitas masyarakat terhadap anak penyandang tuna grahita menjadi tiga kelompok yaitu: orang tua yang bersikap biasa-biasa saja (wajar), orang tua yang bersikap menolak dan keluarga yang bersikap over protective. 
Pada dasarnya orang tua yang bersikap wajar atau biasa-biasa saja terhadap kehadiran seorang anak penyandang tuna grahita di tengah keluarga mereka, akan memperlakukan anak tersebut sama seperti mereka memperlakukan anak-anak yang lainnya. Dan mereka juga tidak pernah berusaha untuk menutup-nutupi keadaan anak mereka tersebut kepada orang lain. Bahkan mereka akan berusaha mencari solusi yang terbaik bagi masa depan anaknya. Misalnya dengan menyekolahkan anaknya di sekolah yang tepat, dimana anaknya bisa menerima pelajaran sesuai dengan kemampuannya, ataupun mendaftarkan anaknya mengikuti program-program bagi anakanak penyandang tuna grahita, dan sebagainya. Sikap atau tindakan orang tua seperti ini akan sangat membantu proses akseptabilitas masyarakat terhadap anak penyandang tuna grahita.

Sikap yang lain adalah sikap menolak yang ditunjukkan oleh orang tua terhadap kehadiran seorang anak penyandang tuna grahita di dalam keluarga mereka. Pada umumnya orang tua mempunyai sikap seperti ini tidak dapat menerima kenyataan yang sebenarnya. Dan mereka merasa sangat malu dan keberatan untuk membawa anak tersebut di depan umum atau di tengah-tengah masyarakat bersama dengan mereka. Biasanya bagi keluarga yang mampu, mereka akan mempekerjakan seorang pembantu atau baby sitter untuk mengasuh anak mereka tersebut, dan menyerahkan segala urusan pengasuhan anak itu kepada pengasuhnya. Sikap orang tua yang seperti ini yang sangat berpengaruh buruk dalam proses akseptabilitas masyarakat terhadap anak penyandang tuna grahita.

Dan klasifikasi yang ketiga adalah sikap yang over protective atau terlalu melindungi. Pada dasarnya sikap seperti dapat mematikan kreatifitas anak dan dapat menyebabkan berkembangnya sikap ketergantungan dan ketidakmandirian dalam diri anak tersebut. Hal ini juga akan berdampak kurang baik dalam proses akseptabilitas masyarakat terhadap anak penyandang tuna grahita.
Berikut klasifikasi tipe orang tua atau keluarga yang memiliki anak penyandang tuna grahita:

\begin{tabular}{|c|c|c|c|}
\hline $\begin{array}{l}\text { Tipe } \\
\text { keluarga }\end{array}$ & $\begin{array}{l}\text { Sikap } \\
\text { terhadap } \\
\text { anak }\end{array}$ & $\begin{array}{l}\text { Motivasi orang } \\
\text { tua }\end{array}$ & $\begin{array}{l}\text { Instrumen } \\
\text { sosialisasi }\end{array}$ \\
\hline $\begin{array}{l}\text { Keluarga } \\
\text { harmonis } \\
\text { / wajar }\end{array}$ & $\begin{array}{l}\text { Menerima } \\
\text { apa } \\
\text { adanya }\end{array}$ & $\begin{array}{l}\text { Menginginkan } \\
\text { kesetaraan } \\
\text { anaknya } \\
\text { dengan yang } \\
\text { lain }\end{array}$ & $\begin{array}{l}\text { 1.Menyekolahkan } \\
\text { anaknya di } \\
\text { SLB-C } \\
\text { 2.Melibatkan } \\
\text { anaknya dalam } \\
\text { kegiatan } \\
\text { kerumahtangga } \\
\mathrm{n} \\
\text { 3.Mengajak } \\
\text { anaknya dalam } \\
\text { kegiatan sosial } \\
\text { 4.Memberi } \\
\text { pengertian } \\
\text { kepada } \\
\text { lingkungan } \\
\text { sosial anaknya, } \\
\text { 5.Tidak } \\
\text { membatasi } \\
\text { pergaulan } \\
\text { anaknya dengan } \\
\text { masyarakat }\end{array}$ \\
\hline $\begin{array}{l}\text { Tipe } \\
\text { keluarga } \\
\text { introvert }\end{array}$ & $\begin{array}{l}\text { Menolak } \\
\text { kehadiran } \\
\text { anak } \\
\text { cacat } \\
\text { tersebut }\end{array}$ & $\begin{array}{l}\text { Menginginkan } \\
\text { agar keadaan } \\
\text { anaknya tidak } \\
\text { diketahui orang } \\
\text { lain }\end{array}$ & $\begin{array}{l}\text { Menyekolahkan } \\
\text { anaknya di SLB- } \\
\text { C }\end{array}$ \\
\hline $\begin{array}{l}\text { Tipe } \\
\text { keluarga } \\
\text { possesive }\end{array}$ & $\begin{array}{l}\text { Over } \\
\text { protective }\end{array}$ & $\begin{array}{l}\text { Takut kalau } \\
\text { anaknya } \\
\text { dicemooh/ } \\
\text { diejek orang } \\
\text { lain }\end{array}$ & $\begin{array}{l}\text { 1. Menyekolahkan } \\
\text { anaknya di } \\
\text { SLB-C } \\
\text { 2.Melibatkan } \\
\text { anak-nya dalan } \\
\text { kegiatan } \\
\text { kerumahtangga } \\
\text { an }\end{array}$ \\
\hline
\end{tabular}

Sumber: data olahan 2016

Pada dasarnya semua tindakan yang dilakukan oleh orang tua anak-anak penyandang tuna grahita merupakan perwujudan dari teori rasionalitas yang dikemukakan oleh Weber. Dimana tindakan-tindakan tersebut didasarkan atas dasar rasionalitas orang tua yang menganggap bahwa dengan melakukan tindakan itu, mereka akan dapat mencapai keinginan atau tujuan mereka, yaitu agar anaknya itu dapat diterima dengan baik oleh masyarakat. Dan hal ini akan melalui suatu proses yang sangat dipengaruhi oleh karakteristik orang tua, kemampuan anak bersosialisasi dan karakteristik lingkungan sosialnya.

Tindakan orang tua anak-anak penyandang tuna grahita yang didasarkan atas rasionalitas instrument adalah dengan menyekolahkan 
anaknya di SLB-C, melibatkan anaknya dalam kegiatan kerumahtanggaan, mengajak anaknya ikut serta dalam kegiatan kemasyarakatan dilingkungan sosialnya, memberi pengertian kepada tetangga/ teman bermain anaknya tentang keadaan anaknya dan tidak membatasi pergaulan anaknya dengan masyarakat atau lingkungan sosialnya. Adapun tindakan-tindakan tersebut dilakukan agar anak penyandang tuna grahita itu dapat bersosialisasi di lingkungan sosial sehingga pada akhirnya akan dapat dicapai rasionalitas nilai seperti yang dikatakan oleh Weber, yaitu akseptabilitas masyarakat terhadap anak tuna grahita.

Berikut bentuk-bentuk akseptabiltas masyarakat terhadap anak penyandang tuna grahita berdasarkan tipe keluarga/ orang tua:

\begin{tabular}{|l|l|}
\hline Tipe keluarga & Bentuk akseptabilitas masyarakat \\
\hline Keluarga & $\begin{array}{l}\text { Masyarakat dapat menerima } \\
\text { dengan baik kehadiran dan } \\
\text { keadaan anak penyandang tuna } \\
\text { grahita di tengah-tengah mereka }\end{array}$ \\
\hline Tipe keluarga introvert & $\begin{array}{l}\text { Masyarakat kurang, atau bahkan } \\
\text { sulit menerima kehadiran dan } \\
\text { keadaan anak penyandang tuna } \\
\text { grahita di lingkungan sosial } \\
\text { mereka }\end{array}$ \\
\hline Tipe keluarga possesive & $\begin{array}{l}\text { Masyarakat kurang dapat } \\
\text { menerima dengan baik kehadiran } \\
\text { dan keadaan anak penyandang } \\
\text { tuna grahita di lingkungansosial } \\
\text { mereka. }\end{array}$ \\
\hline
\end{tabular}

Sumber: data olahan 2016

Dari beberapa tanggapan yang diberikan oleh masyarakat yang tinggal di lingkungan sosial anak-anak penyandang tuna grahita, peneliti melihat bahwa akseptabilitas atau penerimaan masyarakat terhadap anak-anak penyandang tuna grahita sangat dipengaruhi oleh peran orang tua anak tersebut. Orang tua anak penyandang tuna grahita yang lebih terbuka dan bisa menerima keterbatasan anaknya sangat mendukung proses akseptabiltas masyarakat terhadap kehadiran anaknya yang menyandang tuna grahita, akan tetapi orang tua yang sulit menerima keterbatasan anaknya juga akan menimbulkan hambatan dalam proses akseptabilitas masyarakat terhadap anaknya yang menyandang tuna grahita tersebut.

\section{PENUTUP}

\section{Simpulan}

Berdasarkan hasil analisis dan pembahasan, maka dapat di tarik kesimpulan bahwa peran orang tua dalam proses akseptabilitas masyarakat terhadap anak penyandang tuna grahita adalah sangat tergantung kepada reaksi mereka terhadap kehadiran anak tersebut di tengah-tengah keluarga mereka. Berdasarkan data di lapangan, ada tiga bentuk reaksi/ sikap para orang tua yang berbeda satu sama lainnya, yaitu;

1. Orang tua yang dapat menerima keadaan anaknya itu apa adanya dan bersikap wajar/normal terhadap anaknya tersebut. Orang tua yang seperti ini akan selalu mengusahakan agar anaknya dapat bersosialisasi dan diterima dengan baik oleh masyarakat. Sehingga masyarakat dapat menerima kehadiran dan keterbatasan anak penyandang tuna grahita di tengah-tengah mereka dengan baik.

2. Orang tua yang tidak dapat menerima keadaan anaknya, dan cendrung bersikap menolak dan menutup-nutupi keterbatasan anaknya yang menyandang tuna grahita. Tindakan orang tua yang seperti ini hanya sebatas menyekolahkan anaknya di SLB-C, tanpa berusaha untuk melibatkan anak-anaknya baik dalam kegiatan kerumahtanggaan maupun kegiatan sosial kemasyarakatan. Sehingga masyarakat pun umumnya cendrung menolak kehadiran anak tersebut dan sering memarginalkan mereka.

3. Orang tua yang bersikap over possessive terhadap anaknya yang menyandang tuna grahita. Mereka biasanya tetap menyekolahkan anaknya di SLB-C, melibatkan anaknya dalam kegiatan kerumahtanggan, tapi sangat membatasi pergaulan anaknya dilingkungan sosialnya. Dalam hal ini masyarakat masih kurang dapat menerima kehadiran anak penyandang tuna grahita di tengah-tengah mereka karena tidak adanya kesempatan bagi mereka untuk bergaul dan memahami keterbatasan anak penyandang tuna grahita tersebut.

\section{Saran}

Sebagai wadah sosialisasi pertama bagi anak, keluarga, terutama orang tua hendaknya dapat menerima kehadiran seorang anak penyandang tuna grahita di tengah-tengah keluarga mereka. Hal itu akan sangat berpengaruh 
terhadap perkembangan seorang anak, baik perkembangan intelligensi, mental dan sosialnya. Sebelum anak tersebut dapat diterima oleh masyarakat luas, ia terlebih dahulu harus dapat diterima oleh keluarganya.

Di samping itu, masyarakat juga hendaknya mau untuk lebih "membuka mata dan hati" mereka mengenai keberadaan anak penyandang tuna grahita di tengah-tengah mereka. Sebab, anak-anak penyandang tuna grahita adalah juga manusia biasa yang mempunyai perasaan dan harga diri. Meskipun mereka cacat, mereka tetap ingin menjalani hidup sebagaimana layaknya orang-orang normal pada umumnya.

\section{DAFTAR PUSTAKA}

Alimandan, 1986, Sosiologi ilmu berparadigma ganda, Jakarta, CV. Rajawali

Berger, Peter L, 1982, Piramida Kurban Musia: Etika Politik dan Perubahan Sosial, Jakarta, LP3ES

Bungin, Burhan. 2004. Metodologi Penelitian Sosial, Surabaya: Airlangga University Press.

Dirdjosisworo, Soedjono, 1985, Azas-azas Sosiologi, Bandung, Armico

Johnson, Doyle Paul, 1986, Teori Sosiologi Klasik dan Modern, terj. RMZ, Lawang, Jakarta, Gramedia

Hermanto, 1994, Lapora Praktek Lapangan (PPL) di SLB-C Negeri 1 BintaranYogyakarta, FIP IKIP Yogyakarta

Moleong, Lexy J. 1989, Metodologi Penelitian Kualitatif, Bandung, CV. Remaja Karya

.1991, Metodologi Penelitian Kualitatif, Bandung, CV. Remaja Karya

Mc. Iver, Robert dan Charles H. Page, 1981, Sosiologi, London, Mc. Millan \& Co. Ltd

Robinson, Philip, 1986, Sosiologi Pendidikan, Jakarta, CV. Rajawali

Sarwono, Sarlito Wirawan, 1987, Masalahmasalah Kemasyarakatan di Indonesia, Jakarta, Pustaka Sinar Harapan
Sarwono, Sarlito Wirawan, 1984, Teori-teori Psikologi Sosial, Jakarta, CV. Rajawali

Suparlan, Y.B, 1983, Pengantar Pendidikan Anak Mental Subnormal, Jakarta, Pustaka Pengarang

Tatiana, 1997, Tuna Rungu dan Masyarakat, Yogyakarta, UGM

Vembriarto, St, 1981, Sosiologi Pendidikan, Yogyakarta, Paramita

Vredenbergt, Jacob, 1978, Metode dan Teknik Penelitian Masyarakat, Jakarta, Gramedia

Weber, Max, Max Weber: The theory of Sosial and Economic Organization, NewYork, The Free Press 